\title{
Penerapan Metode RUP pada Sistem Informasi Unit Kegiatan Mahasiswa STMIK PalComTech
}

\author{
Andika Widyanto \\ Program Studi Sistem Informasi \\ STMIK PalComTech \\ Palembang, Indonesia \\ andika_widyanto@palcomtech.ac.id
}

\begin{abstract}
Student Activity Unit (UKM) is a place where students gather who have the same interests and interests in a college. STMIK PalComTech is a private tertiary institution in the city of Palembang which has 5 UKM. When registering prospective SME members, they visited the UKM booths that were opened by the UKM management, besides that there were several other obstacles such as UKM STMIK PalComTech activities recorded manually only from the side PalComTech STMIK Student Affairs, which contains the name of the PIC, date of activity, number, name of UKM, place, start, finish, number of attendance, meetings to, information, there is also data material that is not neatly organized, and monthly report collection. In order to support the recording of activities in terms of attendance, members and material taught up to UKM member registration, the researchers created a web-based SME information system using the Rational Unified Process method and in this study using black box testing. RUP is a method that uses the concept of object oriented, and has activities that focus on the development of the model by using the Unified Modeling Language (UML). The results of this study are an information system that can be used, UKM members, and STMIK PalComTech student affairs that make it easy to collect attendance information, member data, activity data, material and announcements.
\end{abstract}

Keywords - information system, student activity unit, stmik palcomtech

Abstrak - Unit Kegiatan Mahasiswa (UKM) adalah sebuah wadah tempat berhimpunnya para mahasiswa yang memiliki kesamaan minat dan kegemaran dalam suatu perguruan tinggi. STMIK PalComTech merupakan sebuah perguruan tinggi swasta di Kota Palembang yang memiliki 5 UKM, pada saat pendaftaran calon anggota UKM mendatangi stan-stan UKM yang telah dibuka oleh pengurus UKM, selain itu terdapat beberapa kendala lain seperti kegiatan UKM STMIK PalComTech tercatat secara manual hanya dari sisi Kemahasiswaan STMIK PalComTech, yang berisi nama PIC, tanggal kegiatan, nomor, nama ukm, tempat, mulai, selesai, jumlah kehadiran, pertemuan ke, keterangan, juga terdapat data materi yang tidak tertata secara rapi, serta pengumpulan laporan bulanan. Guna mendukung pencatatan kegiatan dalam sisi absensi, anggota dan materi yang diajarkan hingga pendaftaran anggota UKM, maka peneliti membuat sebuah sistem informasi UKM berbasis web dengan menggunakan metode Rational Unified Process, pada penelitian ini menggunakan pengujian black box testing. RUP merupakan metode yang menggunakan konsep object oriented, dan memiliki aktifitas yang berfokus pada perkembangan model dengan menggunakan Unified Modelling Language (UML). Hasil dari penelitian ini adalah sebuah sistem informasi yang dapat digunakan perangkat UKM, anggota UKM, dan bagian kemahasiswaan STMIK PalComTech yang memudahkan dalam menghimpun informasi absensi, data anggota, data kegiatan, materi dan pengumuman.

Kata Kunci-sistem informasi, unit kegiatan mahasiswa, stmik palcomtech

\section{PENDAHULUAN}

STMIK PalComTech merupakan sebuah perguruan swasta di Kota Palembang yang memiliki Unit Kegiatan Mahasiswa (UKM), digunakan sebagai wadah untuk menghimpun mahasiswa yang memiliki kegemaran dan minat yang sama. Unit Kegiatan Mahasiswa STMIK PalComTech sendiri berjumlah 5 UKM, yang masing-masing bernama UKM PalComTech Broadcasting, UKM PalComTech Digital Art, UKM PalComTech Open Source, UKM PalComTech Photography, dan UKM PalComTech Programming. Unit Kegiatan Mahasiswa sendiri merupakan sebuah lembaga kemahasiswaan tempat berhimpunnya para mahasiswa yang memiliki kesamaan minat, kegemaran, kreativitas, dan orientasi aktivitas penyaluran kegiatan ekstrakulikuler di kampus[1].

UKM-UKM yang berada di STMIK PalComTech sendiri pada saat masa pendaftarannya masih menggunakan cara yang konvensional dengan datang ke stan-stan yang telah dibuka oleh masing-masing UKM PalComTech, selain dari itu terdapat beberapa kendala seperti pihak kemahasiswaan STMIK PalComTech melakukan pencatatan untuk mengetahui aktivitas dari masing-masing UKM yang berisi nama PIC, tanggal kegiatan, nomor, nama ukm, tempat, mulai, selesai, jumlah kehadiran, pertemuan ke, keterangan, juga terdapat data materi yang tidak tertata secara rapi, serta pengumpulan laporan bulanan.

Berdasarkan penelitian yang sudah dilakukan sebelumnya antara lain, membahas sistem informasi e-commerce untuk jaringan penjualan sepeda motor bekas Kabupaten Kampar menggunakan metode rational unified proccess dan object oriented analysis and design dan pengujiannya dilakukan 
menggunakan blackbox dan user acceptance test. Adapun hasil penelitian ini adalah bagaimana sistem yang sedang berjalan dapat dikembangkan menjadi lebih baik melalui analisis dan desain sehingga menghasilkan sistem ECommerce. Kesimpulan dari penelitian ini adalah Sistem ECommerce dapat memperluas dalam segi promosi dan memudahkan konsumen dalam membeli dan memilih sepeda motor yang diinginkan[2].

Pembangunan sistem informasi pengelolaan surat pada komisi pemilihan umum Kota Palembang. Sistem informasi pengelolaan surat yang akan dibangun pada KPU dikembangkan dengan rancangan model UML (Unifed Model Language), pengembangan sistem menggunakan RUP (Rational Unified Process), dibangun berbasis website dengan bahasa pemograman PHP dan MySQL[3].

Sistem informasi adalah pengaturan orang, data, proses dan Teknologi Informasi (IT) yang berinteraksi untuk mengoleksi, memproses, menyimpan, dan menyediakan hasil berupa informasi yang diperlukan untuk mendukung sebuah organisasi[4]. Sistem informasi juga bisa diartikan sebagai kesatuan elemen informasi, termasuk cara mendesain, mengaktifkan, mengatasi, memelihara, dan memanfaatkan informasi[5]. Sementara itu dijelaskan juga sistem informasi UKM adalah suatu sistem yang dibuat manusia yang terdiri dari komponen berbasis komputer dan manual yang menyediakan informasi bagi pengurus, anggota serta orang lain di luar organisasi yang berkepentingan[6]. Website yang menjelaskan profil perusahaan pada PT. Cinta Kasih Pribadina dengan implementasi metode Rational Unified Process (RUP). RUP merupakan metode yang menggunakan konsep object oriented, dan memiliki aktifitas yang berfokus pada pengembangan model dengan menggunakan Unified Model Language (UML), memiliki tahapan-tahapan seperti inception (permulaan), elaboration (perluasan atau perencanaan), construction (konstruksi), transition (transisi) sehingga sangat tepat dalam menerapkan metode tersebut pada website PT. Cinta Kasih Pribadina [7]. Pada penelitian terdahulu, yang berjudul aplikasi unit kegiatan mahasiswa (UKM) pada STMIK Mura Lubuk Linggau berbasis web, menyimpulkan bahwa website digunakan untuk menyampaikan informasi dan memberikan data dengan cepat, tepat, dan akurat[8].

Berdasarkan uraian di atas yang telah dijelaskan inilah peneliti berinisiatif untuk membangun sebuah sistem informasi unit kegiatan mahasiswa STMIK PalComTech yang berfungsi untuk menampung data-data anggota, absensi, kegiatan, materi dan sebagainya yang dibutuhkan oleh semua pihak terkait dengan menggunakan metode RUP, dikarenakan proses RUP cocok dalam pembangunan sistem informasi karena memiliki tahapan-tahapan seperti inception (permulaan), elaboration (perluasan atau perencanaan, construction (konstruksi), transition (transisi).

\section{METODOLOGI}

Sistem Informasi UKM STMIK PalComTech dirancang dan dibangun menggunakan bahasa pemrograman PHP versi 7.1 dengan basis data MySQL, secara umum Sistem Informasi ini dibangun untuk memudahkan proses pendaftaran, absensi kegiatan, pengumuman, informasi materi dan beberapa hal lainnya yang terkait dengan UKM STMIK PalComTech.

Sedangkan penelitian yang dilakukan oleh Sofian Sauri, yang berjudul Sistem Informasi unit kegiatan mahasiswa (UKM) sepakbola universitas mulawarman berbasis web, menyimpulkan bahwa dengan adanya Sistem Informasi UKM dapat digunakan sebagai alat bantu dalam penyampaian informasi teknologi dan komunikasi UKM itu sendiri dan dengan adanya Sistem Informasi UKM ini mengatasi kurangnya minat mahasiswa untuk mendaftar UKM, serta dapat dijadikan solusi yang berguna. Dari beberapa penelitian terdahulu, terlihat bahwa Sistem Informasi UKM dapat membantu pihak-pihak terkait dalam mengatasi kekurangankekurangan yang ada pada aktivitas pencatatan dan kegiatan lainnya, seperti pendaftaran UKM yang semakin meningkat setelah website UKM tersebut dibuat.

Pada pembuatan Sistem Informasi UKM STMIK PalComTech ini, peneliti menggunakan metode Rational Unified Process, seperti dijelaskan pada penelitian yang dilakukan oleh Usman Ependi, bahwa Rational Unified Process (RUP) adalah pendekatan pengembangan perangkat lunak yang dilakukan berulang-ulang (iterative), tertuju pada arsitektur (arsitektur-centric), dan lebih diarahkan berdasarkan permasalahan yang dihadapi (use case driven).

RUP menyediakan pendefinisian struktur yang baik untuk alur hidup proyek perangkat lunak. Metode RUP mempunyai 4 (empat) fase, yaitu:

\section{A. Fase inception}

Tahap pertama ini kita memodelkan proses bisnis yang dibutuhkan (business modelling) dan mendefinisikan kebutuhan akan sistem yang akan dibuat (requirements).

\section{B. Fase elaboration}

Tahap kedua lebih ditujukan pada perencanaan arsitektur sistem. Tahap ini lebih pada analisis dan desain sistem.

\section{Fase construction}

Tahap ketiga, dimana kita mengembangkan komponen dan fitur-fitur sistem. Implementasi dan pengujian sistem yang tertuju pada implementasi perangkat lunak pada kode program.

\section{Fase transition}

Tahap dimana kita deployment atau instalasi sistem agar dapat digunakan dan dipahami oleh pengguna (user). Aktifitas pada tahap ini termasuk pada pelatihan pengguna dan pemeliharaan. Adapun proses iteratif RUP dapat dilihat pada gambar 1.

Pada penelitian ini, peneliti juga menggunakan pengujian black box testing, black box testing berfokus pada spesifikasi fungsional dari perangkat lunak. Pengujian perangkat lunak dari segi spesifikasi fungsional tanpa menguji desain dan kode program untuk mengetahui apakah fungsi, masukan dan keluaran dari perangkat lunak sesuai dengan spesifikasi yang dibutuhkan. Metode black box testing merupakan salah satu metode yang mudah digunakan karena hanya memerlukan batas bawah dan batas atas dari data yang diharapkan, Estimasi banyaknya data uji dapat dihitung melalui banyaknya 
field data entri yang akan diuji, aturan entri yang harus dipenuhi serta kasus batas atas dan batas bawah yang memenuhi.

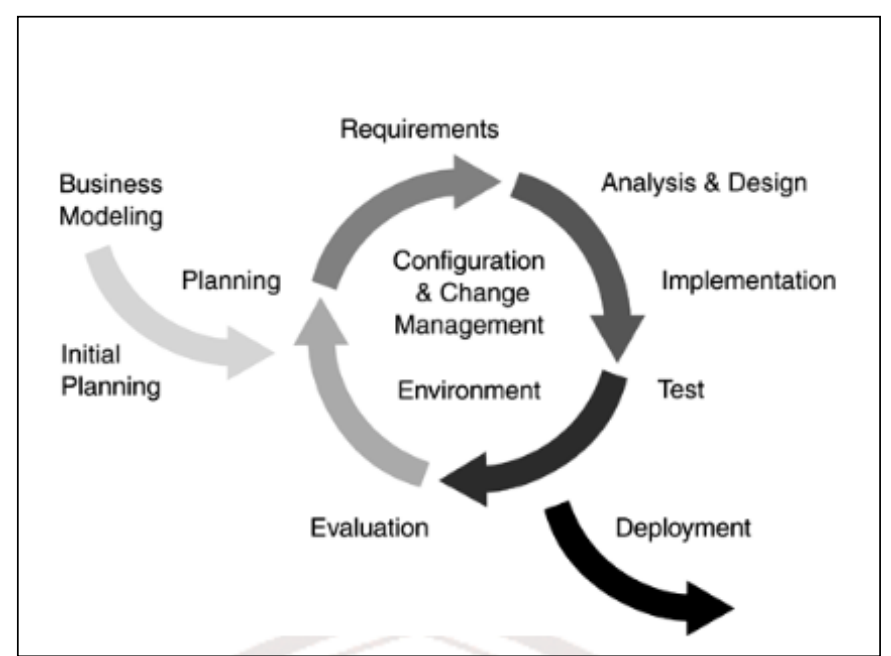

Gambar 1. Proses Iteratif RUP

Sumber: Rossa, A S dan M. Shalahuddin, 2014

Dan dengan metode ini dapat diketahui jika fungsionalitas masih dapat menerima masukan data yang tidak diharapkan maka menyebabkan data yang disimpan kurang valid[9]. Solusi praktis peningkatan akurasi perlu dilakukan segera guna memperbaiki celah error yang telah ditemukan, selanjutnya dilakukan pengujian keamanan secara intensif melalui jaringan internal (whitebox penetration testing) secara berkala oleh System Administrator atau Pengelola Sistem Informasi, khususnya bagi yang mengelola perangkat lunak tersebut dan Untuk mencapai tingkat akurasi, dimana semua parameter akurasi yang terkait aspek kerahasiaan, integritas data, dan avalibilitas data dapat terpenuhi, maka harus dipertimbangkan metode lain yang, Pengujian Black Box Testing dapat dijadikan tolak ukur standar keamanan informasi[10].

\section{HASIL DAN PEMBAHASAN}

\section{A. Fase Inception}

Tahapan ini digunakan untuk menggali kebutuhan terhadap pengembangan sistem pangkalan data tanaman obat. Tahapan ini digunakan untuk memodelkan proses bisnis yang dijalankan dan mengusulkan proses bisnis yang baru. Target pengguna dalam sistem ini adalah anggota UKM, kemahasiswaan, dan pengurus UKM yang melakukan kegiatan/aktivitas UKM di STMIK PalComTech. Fase inception mempunyai dua tahap, yaitu:

\section{1) Business Modelling}

Business modelling sebagai suatu teknik pemodelan yang digunakan untuk menggambarkan model sebuah bisnis. Business modelling digunakan untuk meninjau, meningkatkan dan membuat sebuah bisnis. Model yang digunakan dalam business modelling yaitu Business Use Case Model yang menggambarkan interaksi proses sistem tersebut dengan pihak luar.

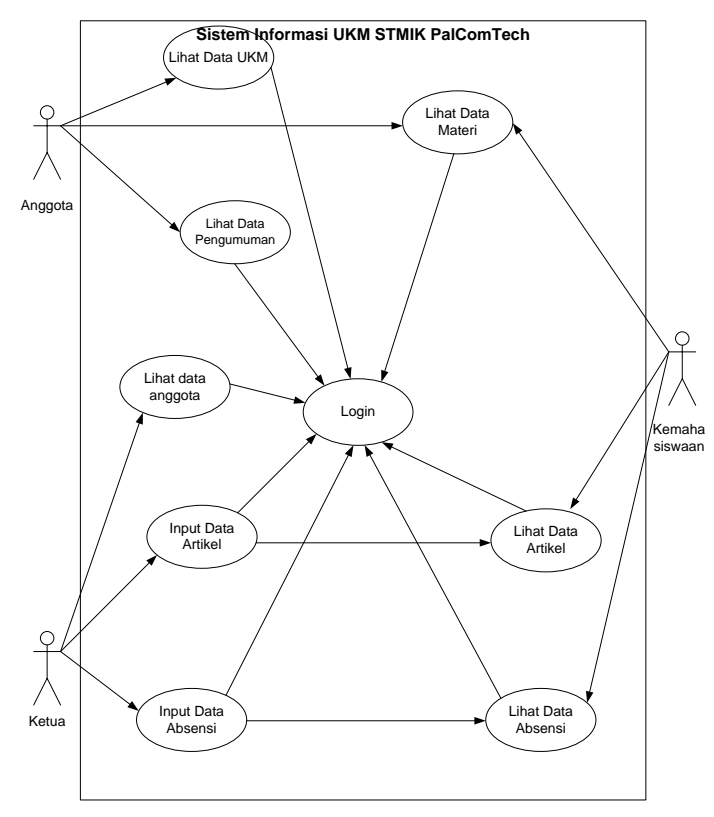

Gambar 2. Business Use Case Model

Pada Business Use Case Model terdiri dari Anggota, Kemahasiswaan dan Anggota yang dibagi menjadi masingmasing keperluannya, seperti Anggota dapat melihat data UKM, melihat data materi dan melihat data pengumuman, sedangkan untuk Ketua dapat melihat data anggota, menginput data artikel dan menginput data absensi, dan untuk Kemahasiswaan dapat melihat data artikel, melihat data absensi dan melihat data materi.

\section{2) Requirement}

Requirement workflow adalah untuk menggambarkan sistem apa yang harus dilakukan. Use case diidentifikasikan untuk mewakili perilaku sistem, Use case diagram ini menggambarkan fungsional yang diharapkan dari sistem informasi UKM STMIK PalComTech. Anggota UKM dapat melihat pengumuman, materi dan data anggota lainnya setelah melakukan login ke sistem. Pengurus UKM dapat menambah pengumuman, materi, anggota baru dan melakukan absensi serta mengupload laporan bulanan setelah login ke sistem, dan yang terakhir adalah kemahasiswaan yang dapat mengakses data-data anggota, absensi serta laporan bulanan tanpa mengubah data di dalam sistem melalui proses login.

\section{B. Fase Elaboration \\ 1) Analisis}

Dari hasil penelitian yang dilakukan peneliti menemukan permasalahan, yaitu calon anggota UKM diwajibkan datang ke stan-stan UKM untuk mendaftar secara langsung, sedangkan tidak semua mahasiswa dapat mengunjungi stanstan tersebut dikarenakan keterbatasan waktu dan tempat, selain itu juga sering terdapat mahasiswa atau calon anggota yang mendaftar lebih dari 1 (satu) UKM pada periode yang bersamaan, selain itu pihak pengurus UKM juga memerlukan waktu yang cukup lama ketika ditanya mengenai data anggota 
UKM, absensi, kegiatan dan materi yang diajarkan, serta pihak kemahasiswaan yang memerlukan waktu juga untuk mengetahui laporan bulanan.

\section{2) Desain}

Activity Diagram yang digunakan untuk menggambarkan workflow (aliran kerja) atau aktivitas dari sebuah sistem atau proses bisnis, diagram aktivitas menggambarkan aktivitasaktivitas sistem bukan apa yang dilakukan aktor[9].

Activity Diagram menggambarkan kegiatan interaksi antara anggota dan sistem. Pada menu utama anggota terdapat data anggota UKM, data UKM, data pengumuman, data materi, sedangkan pada menu utama unit kemahasiswaan menampilkan data-data seperti, data UKM, data anggota UKM, data registrasi user baru, data pengumuman, data materi, data absensi, data laporan, artikel, dan galeri. Adapun menu-menu yang ada pada tampilan ketua UKM adalah data user, data registrasi user, data UKM, data pengumuman, data materi, data absensi, data laporan, data artikel, dan data galeri.

Adapun gambaran activity diagram anggota UKM dapat dilihat pada gambar 3 .

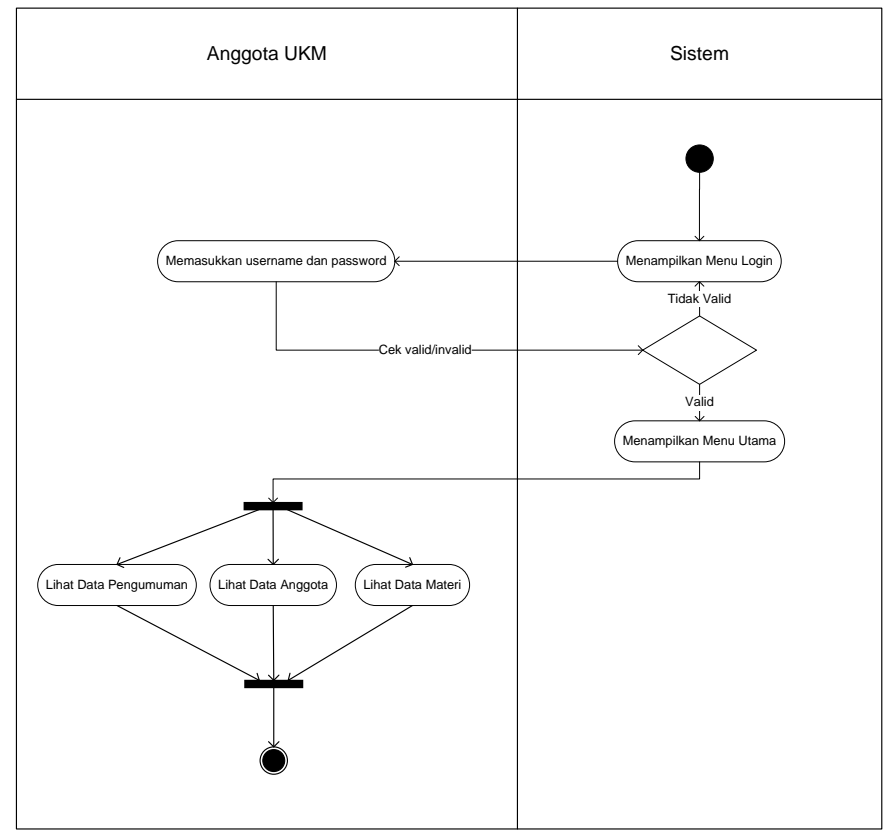

Gambar 3. Activity Diagram Anggota UKM

Pada activity diagram anggota UKM dapat dijelaskan bahwa anggota UKM login ke sistem informasi dan akan di validasi username dan passwordnya, apabila username dan password valid, sistem menampilkan menu utama sehingga anggota UKM dapat melihat data pengumuman, melihat data anggota dan melihat data materi

Activity Diagram yang menjelaskan aktivitas pengurus UKM dapat dilihat pada gambar 4.

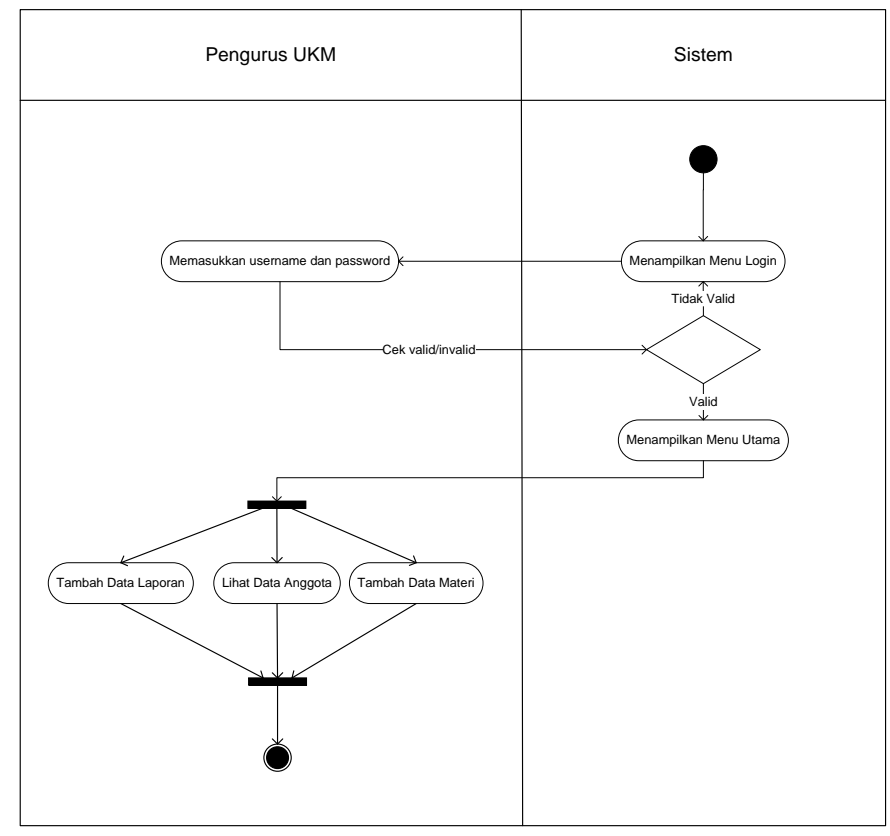

Gambar 4. Activity Diagram Pengurus UKM

Pada activity diagram pengurus UKM dapat dijelaskan bahwa pengurus UKM login ke sistem informasi dan akan di validasi username dan passwordnya, apabila username dan password valid, sistem menampilkan menu utama sehingga pengurus UKM dapat menambah data laporan, melihat data anggota dan menambah data materi

Activity Diagram yang menjelaskan kemahasiswaan dapat dilihat pada gambar 5 .

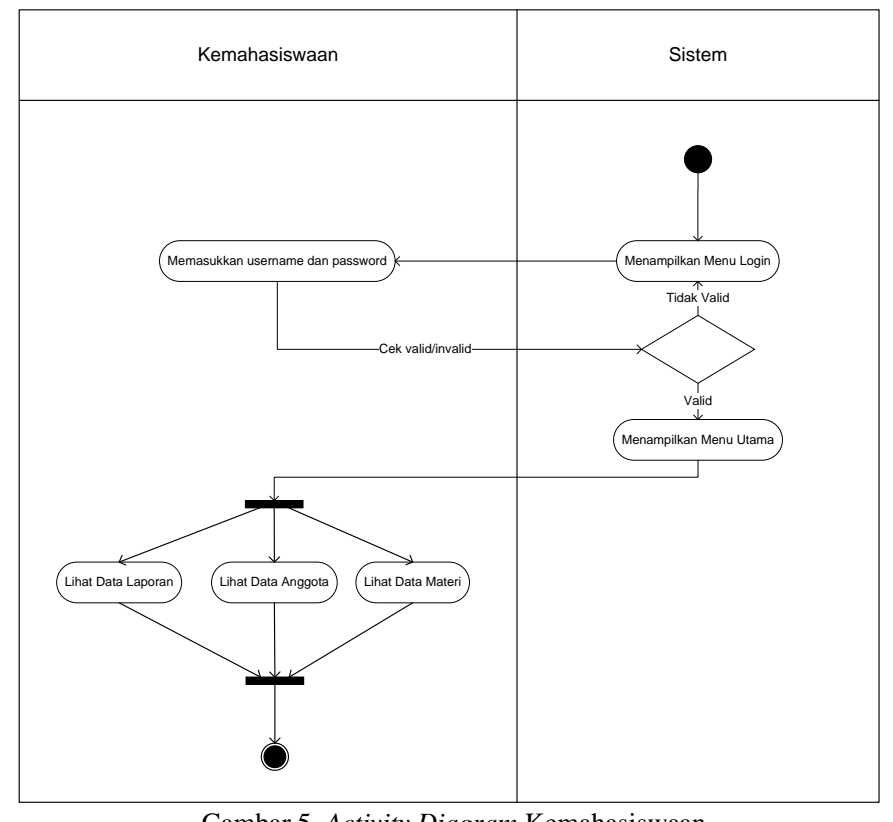

Gambar 5. Activity Diagram Kemahasiswaan

Pada gambar 5 activity diagram kemahasiswaan dapat dijelaskan bahwa kemahasiswaan login ke sistem informasi dan akan di validasi username dan passwordnya, apabila username dan password valid, sistem menampilkan menu 
utama sehingga kemahasiswaan dapat melihat data laporan, melihat data anggota dan melihat data materi.

3) Desain Struktur Menu

a) Rancangan Tampilan Utama

Rancangan tampilan utama merupakan menu atau tampilan halaman awal pada sistem informasi UKM PalComTech, adapun tampilan utama dapat dilihat pada gambar 6, di bawah ini.

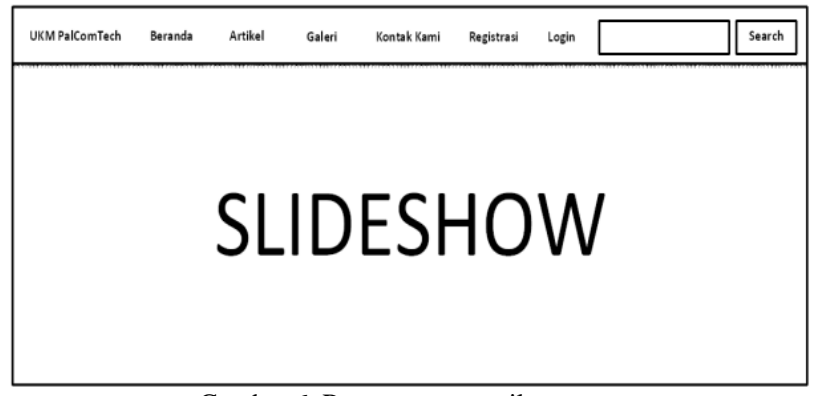

Gambar 6. Rancangan tampilan utama

Pada rancangan tampilan utama terdapat beberapa menu, yaitu beranda, artikel, galeri, kontak kami, registrasi, login dan form pencarian.

\section{b) Rancangan Menu Registrasi Calon Anggota}

Menu ini merupakan sebuah tampilan form yang digunakan untuk registrasi calon anggota baru, calon anggota baru dapat mengisi data diri dan memilih UKM yang ingin diikuti. Tampilan formulir registrasi calon anggota ini dapat dilihat pada gambar 7 .

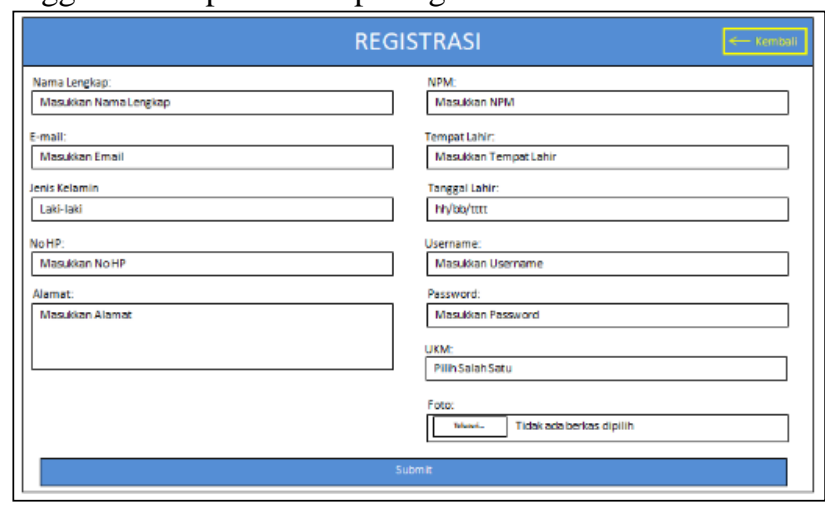

Gambar 7. Rancangan registrasi calon anggota

Pada rancangan menu registrasi calon anggota terdiri dari sebuah form registrasi yang berisi nama lengkap, email, jenis kelain, no hp, alamat, npm, tempat lahir, tanggal lahir, username, password, UKM, foto.

\section{c) Rancangan tampilan form login}

Rancangan tampilan form login merupakan tampilan form yang digunakan untuk login anggota baru, anggota baru cukup dengan memasukkan username dan password. Tampilan form login dapat dilihat pada gambar 8 , berikut ini.

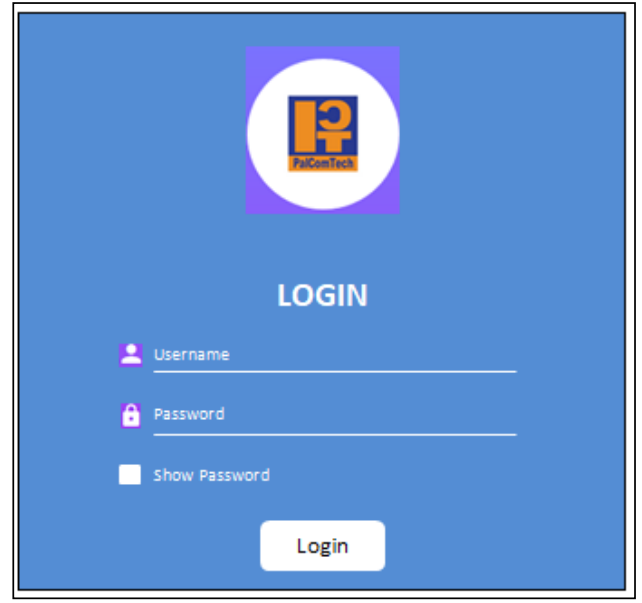

Gambar 8. Rancangan tampilan form login

Pada rancangan tampilan form login terdiri dari sebuah form yang berisi username, password, show password.

d) Rancangan tampilan data anggota

Rancangan tampilan data anggota merupakan tampilan yang digunakan untuk melihat data anggota UKM yang sudah melakukan registrasi, tampilan ini dapat dilihat pada gambar 9 .

\begin{tabular}{|c|c|c|c|}
\hline \multicolumn{4}{|c|}{ Data Anggota } \\
\hline No & NPM & Nama & UKM \\
\hline$x x x x x x$ & $x x x x x x$ & $x x x x x x$ & $x x x x x x$ \\
\hline$x x x x x x$ & $x x x x x x$ & $x x x x x x$ & $x x x x x x$ \\
\hline $\mathrm{xxx \textrm {xxx }}$ & $x x x x x x$ & $x \mathrm{xx} x \mathrm{xx}$ & $x x x x x x$ \\
\hline$x \mathrm{xx} x \mathrm{xxx}$ & $x \mathrm{x} x \mathrm{x} x \mathrm{x}$ & $x \mathrm{xx} x \mathrm{xx}$ & $x \mathrm{xx} x \mathrm{xx}$ \\
\hline
\end{tabular}

Gambar 9. Rancangan tampilan data anggota

Pada rancangan tampilan data anggota terdiri dari no, npm, nama dan UKM.

e) Rancangan tampilan data UKM

Rancangan tampilan data UKM merupakan tampilan yang digunakan untuk melihat data UKM yang terdaftar di STMIK PalComTech, adapun rancangan tampilan data UKM ini dapat dilihat pada gambar 10.

\begin{tabular}{|c|c|c|c|}
\hline \multicolumn{4}{|c|}{ Data UKM } \\
\hline No & Nama UKM & Total Anggota Aktif & Total Anggota Non Aktif \\
\hline$x x x x x x$ & $x x x x x x$ & $x x x x x x$ & $x x x x x x$ \\
\hline$x x x x x x$ & $x \mathrm{xxxxx}$ & $x x x x x x$ & $x x x x x x$ \\
\hline$x x x x x x$ & $x x x x x x$ & $x x x x x x$ & $x x x x x x$ \\
\hline$x x x x x x$ & $x x x x x x$ & $x x x x x x$ & $x x x x x x$ \\
\hline
\end{tabular}

Gambar 10. Rancangan tampilan data UKM

Pada rancangan tampilan data UKM terdiri dari no, nama UKM, total anggota aktif dan total anggota non 
aktif.

f) Rancangan tampilan data pengumuman

Rancangan tampilan data pengumuman merupakan tampilan yang digunakan untuk melihat data pengumuman yang akan diumumkan kepada semua anggota UKM, tampilan data pengumuman dapat dilihat pada gambar 11 .

\begin{tabular}{|c|c|c|}
\hline \multicolumn{3}{|c|}{ Pengumuman } \\
\hline No & Judul Pengumuman & Tanggal Posting \\
\hline$x x x x x x$ & $x x x x x x$ & $x x x x x x$ \\
\hline$x x x x x x$ & $x x x x x x$ & $x x x x x x$ \\
\hline$x x x x x x$ & $x x x x x x$ & $x x x x x x$ \\
\hline$x x x x x x$ & $x x x x x x$ & $x x x x x x$ \\
\hline
\end{tabular}

Gambar 11. Rancangan tampilan data pengumuman

Pada rancangan tampilan data pengumuman terdiri dari no, judul pengumuman, tanggal posting.

g) Rancangan tampilan data materi

Rancangan tampilan data materi adalah tampilan yang digunakan untuk melihat data-data materi yang diinput oleh ketua-ketua UKM, tampilan data materi tersebut dapat dilihat pada gambar 12 .

\begin{tabular}{|c|c|c|c|c|}
\hline \multicolumn{5}{|c|}{ Data Materi } \\
\hline No & Judul Materi & Tanggal Posting & UKM & Action \\
\hline$x x x x x x$ & $x x x x x x$ & $x x x x x x$ & $x x x x x x$ & $x x x x x x$ \\
\hline$x x x x x x$ & $x x x x x x$ & $x x x x x x$ & $x x x x x x$ & $x x x x x$ \\
\hline$x x x x x x$ & $x x x x x x$ & $x x x x x x$ & $x x x x x x$ & $x x x x x x$ \\
\hline$x x x x x x$ & $x x x x x x$ & $x x x x x x$ & $x x x x x x$ & $x x x x x$ \\
\hline
\end{tabular}

Gambar 12. Tampilan data materi

Pada rancangan tampilan data materi terdiri dari no, judul materi, tanggal posting, UKM, action.

\section{h) Rancangan tampilan data absensi}

Rancangan tampilan data absensi adalah tampilan yang digunakan untuk melihat data-data absensi yang diinput oleh ketua UKM, tampilan data materi tersebut dapat dilihat pada gambar 13 .

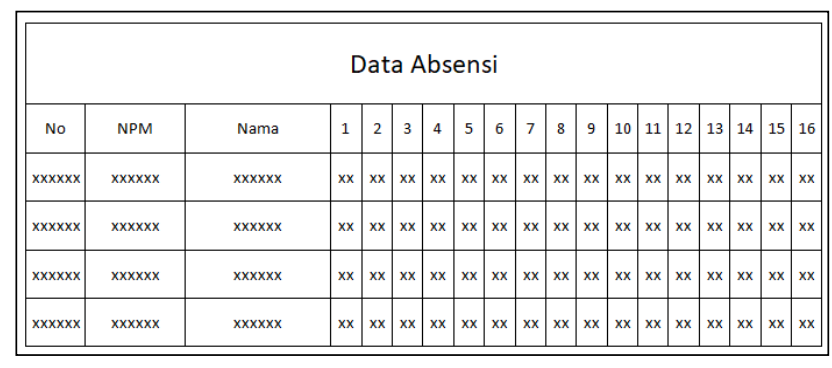

Gambar 13. Tampilan data absensi
Pada rancangan tampilan data absensi terdiri dari no, npm, nama, dan data kehadiran per pertemuan.

\section{Fase Constructions \\ 1) Implementasi}

Hasil dari penelitian yang telah dilakukan di STMIK PalComTech adalah Sistem Informasi UKM STMIK PalComTech menggunakan metode RUP dengan bahasa pemrograman PHP versi 7.1 dan database MySQL. Sistem informasi ini dibuat untuk mempermudah proses pendaftaran calon anggota UKM, dan proses absensi, mendapatkan materi serta laporan bulanan UKM. Dalam hal proses pendaftaran, calon anggota UKM tidak harus datang ke stan-stan UKM yang biasanya dibuka, hal ini juga dapat mengurangi pengeluaran UKM untuk mencetak banner dan pendataan anggota yang lebih rapi dibandingkan dengan periode sebelumnya.

Pada tahap implementasi ini sistem informasi UKM STMIK PalComTech, memiliki 2 tampilan yaitu halaman depan dan halaman dashboard. Pada halaman depan terdapat 5 menu, yaitu beranda, artikel, galeri, kontak kami, registrasi dan login, sedangkan untuk halaman dashboard terdapat beberapa menu yang dibedakan untuk beberapa level pengguna. Pada halaman beranda, terdapat beberapa tampilan yaitu slideshow, pengenalan UKM dan artikel terbaru. Sedangkan pada menu artikel terdapat tampilan artikel-artikel yang telah diposting oleh ketua-ketua UKM dan admin, untuk galeri terdapat tampilan gambar-gambar yang berhubungan dengan kegiatan UKM, sedangkan untuk kontak kami adalah tampilan yang digunakan untuk pengunjung sistem informasi apabila ada yang ingin ditanyakan, lalu ada menu registrasi dimana tampilan ini berfungsi sebagai tempat calon anggota registrasi, dan menu login adalah tempat anggota dan pengguna masuk ke dalam sistem informasi.

Adapun tampilan halaman beranda yang telah dihasilkan adalah seperti gambar 14 ini.

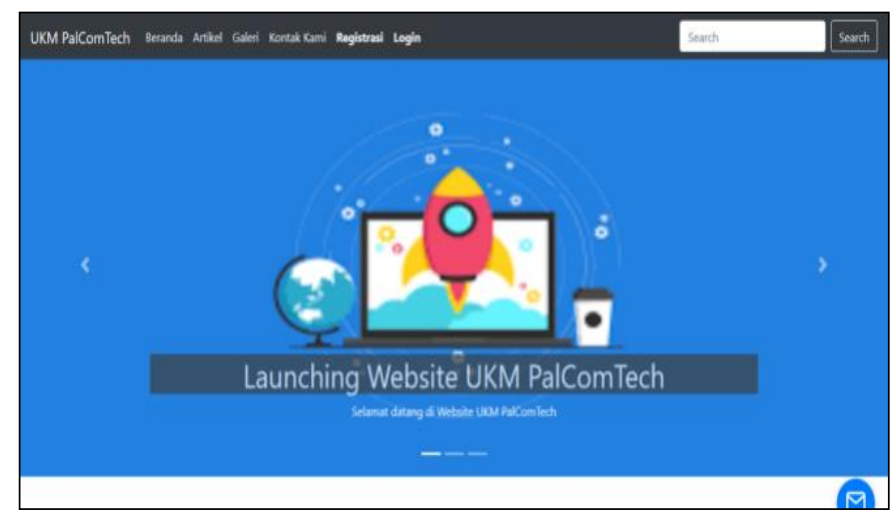

Gambar 14. Tampilan halaman beranda

Tampilan halaman artikel yang telah diimplementasikan dapat dilihat pada gambar 15 berikut ini. 


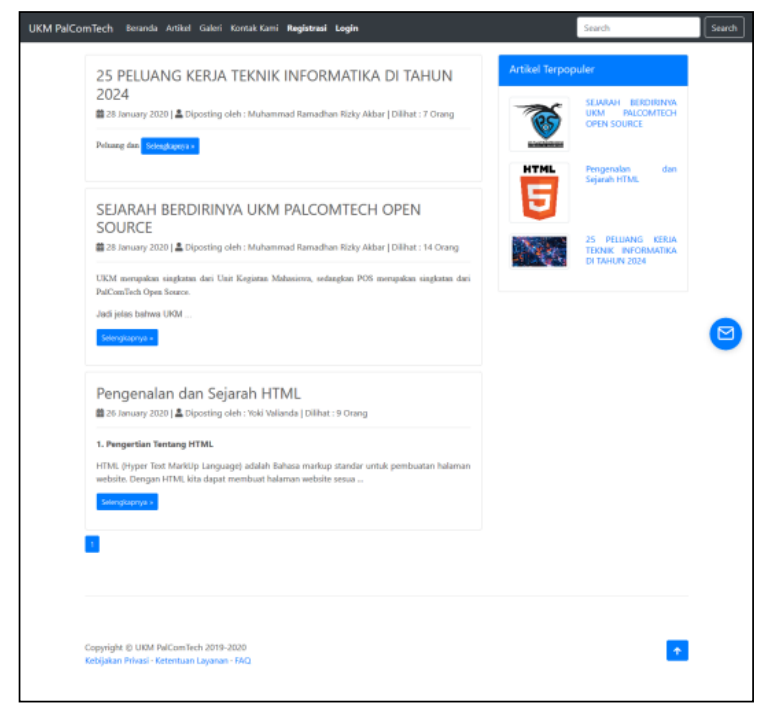

Gambar 15. Tampilan halaman artikel

Tampilan halaman galeri yang berisi foto-foto kegiatan UKM dapat dilihat pada gambar 16.

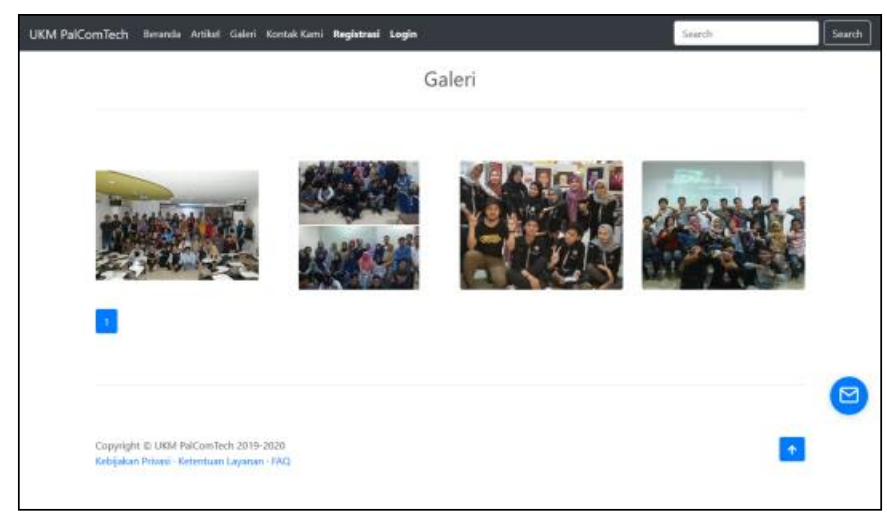

Gambar 16. Tampilan halaman galeri

Tampilan halaman kontak kami yang berisi sebuah formulir yang dapat diisi pengunjung sistem informasi UKM STMIK PalComTech, tampilan ini dapat dilihat pada gambar 17.

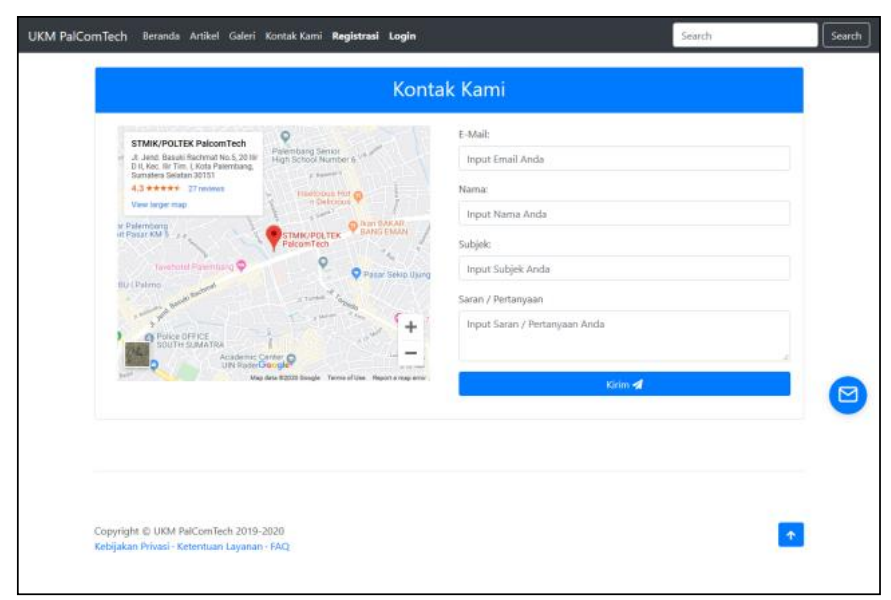

Gambar 17. Tampilan halaman kontak kami
Tampilan halaman registrasi yang berisi sebuah formulir yang diisi oleh calon anggota UKM STMIK PalComTech dan dapat dilihat pada gambar 18.

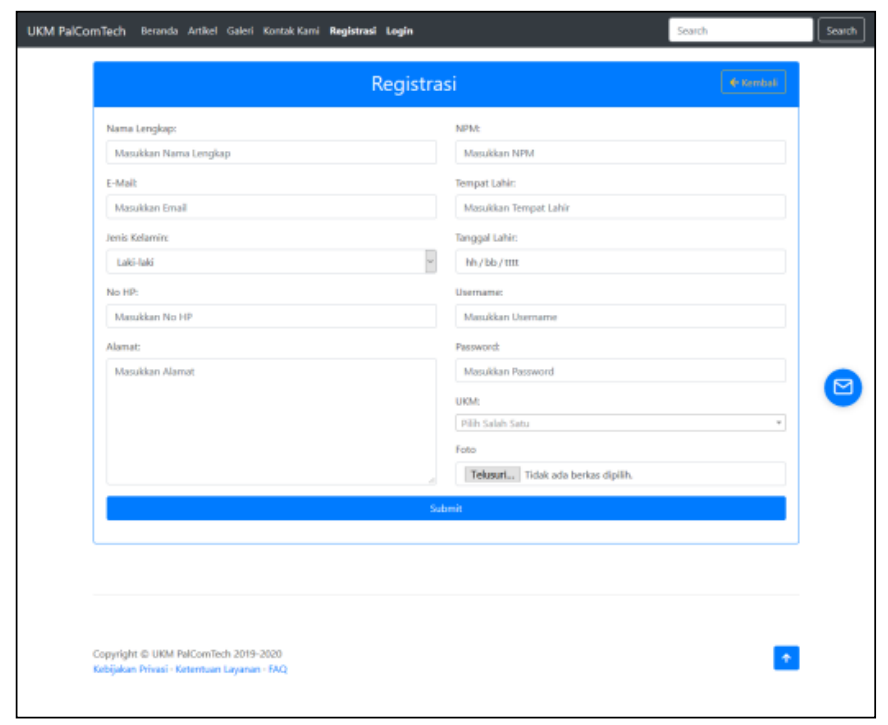

Gambar 18. Tampilan halaman registrasi

Tampilan halaman login yang berisi sebuah formulir untuk masuk ke dalam sistem informasi UKM STMIK PalComTech yang dapat dilihat pada gambar 19 .

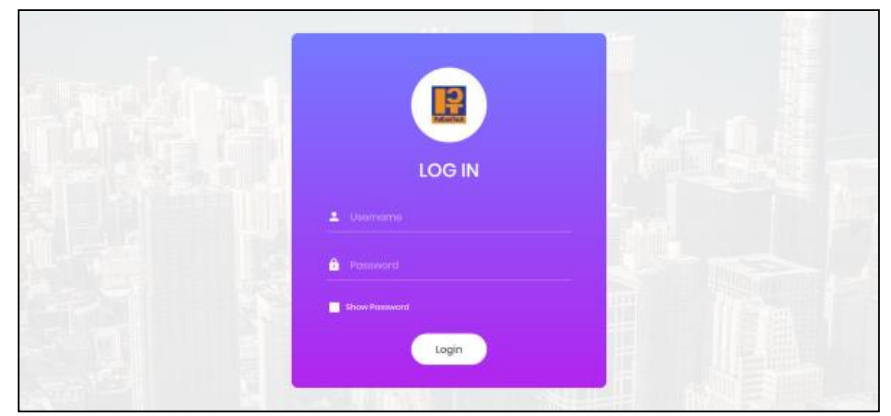

Gambar 19. Tampilan halaman login

Pada halaman dashboard terdapat beberapa menu yang dapat digunakan oleh pengguna yang dibagi menjadi 4 level, yaitu super admin, ketua UKM, kemahasiswaan dan anggota UKM. Adapun menu-menu yang ada pada ketua UKM adalah data anggota, data registrasi user, data UKM, data pengumuman, data materi, data absensi, dan data laporan. Sedangkan untuk menu yang ada pada anggota adalah data anggota, data UKM, data pengumuman, dan data materi.

Pada tampilan halaman registrasi user atau calon anggota dapat dilihat pada gambar 20 berikut ini. 


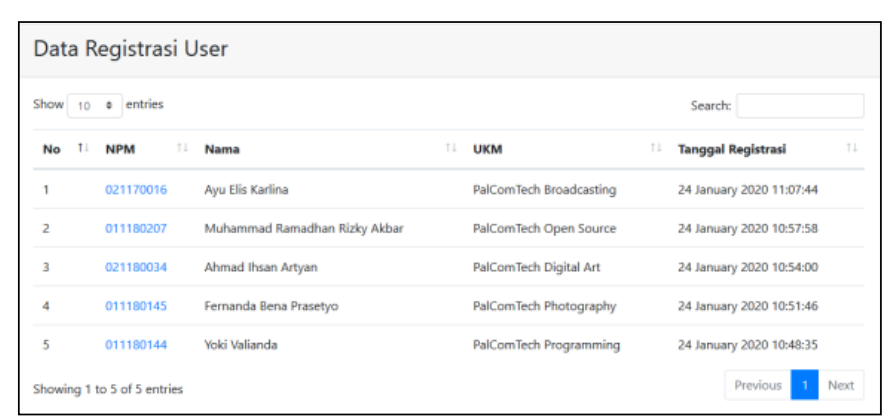

Gambar 20. Tampilan halaman registrasi user

Pada tampilan halaman data UKM yang berisi data mengenai informasi UKM, seperti yang dapat dilihat pada gambar 21.

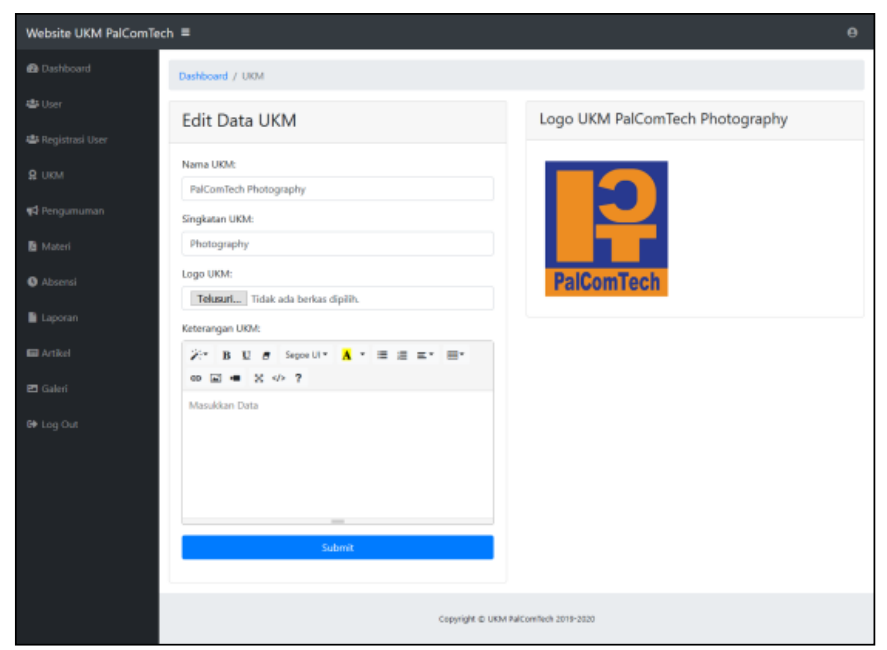

Gambar 21. Tampilan halaman data UKM

Pada tampilan halaman pengumuman yang berisi mengenai informasi pengumuman-pengumuman yang berkaitan dengan kegiatan UKM STMIK PalComTech, tampilan ini dapat dilihat pada gambar 22.

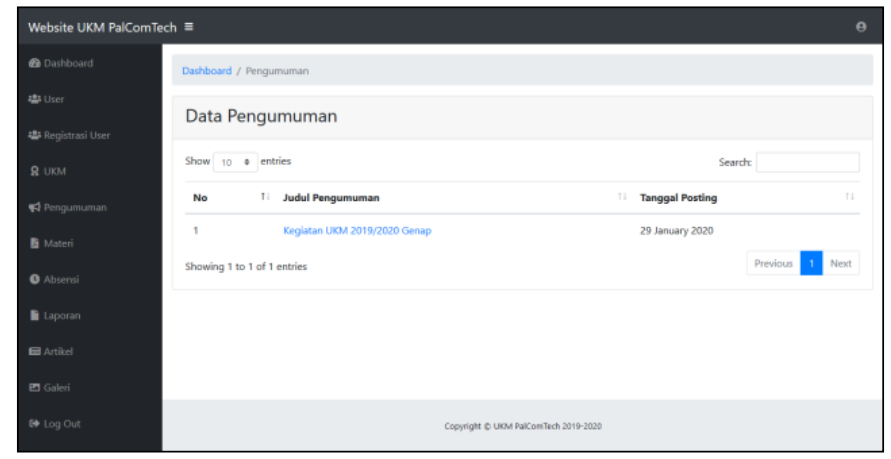

Gambar 22. Tampilan halaman data pengumuman

Pada penelitian ini, peneliti menggunakan pengujian black box testing untuk menguji sistem informasi UKM STMIK PalComTech, adapun yang diuji pada sistem informasi UKM STMIK PalComTech adalah sebagai berikut:

- Fungsi yang tidak benar atau tidak ada.

- Kesalahan antarmuka (interface errors)
- Kesalahan pada struktur data dan akses basis data.

- Kesalahan performansi (performance errors)

- Kesalahan inisialisasi dan terminasi.

Hasil pengujian dilakukan terhadap sistem informasi. Pengguna menggunakan sistem informasi, kemudian melakukan pengujian dengan perolehan hasil seperti pada tabel 1 .

Tabel 1. Hasil Pengujian Black Box Testing Login Admin

\begin{tabular}{|c|c|c|c|c|c|}
\hline No & $\begin{array}{c}\text { Skenario } \\
\text { Pengujian }\end{array}$ & Test Case & $\begin{array}{c}\text { Hasil yang } \\
\text { diharapkan }\end{array}$ & $\begin{array}{c}\text { Hasil } \\
\text { Pengujian }\end{array}$ & $\begin{array}{l}\text { Kesim } \\
\text { pulan }\end{array}$ \\
\hline 1 & $\begin{array}{l}\text { Username } \\
\text { dan } \\
\text { Password } \\
\text { tidak diisi } \\
\text { kemudian } \\
\text { klik } \\
\text { tombol } \\
\text { Login }\end{array}$ & $\begin{array}{l}\text { Username } \\
\text { : (kosong) } \\
\text { Password: } \\
\text { (kosong) }\end{array}$ & $\begin{array}{l}\text { Sistem akan } \\
\text { menolak dan } \\
\text { menampilka } \\
\text { n pesan } \\
\text { "Harap isi } \\
\text { username } \\
\text { dan } \\
\text { password" }\end{array}$ & $\begin{array}{l}\text { Sesuai } \\
\text { harapan }\end{array}$ & Valid \\
\hline 2 & $\begin{array}{l}\text { Mengetikk } \\
\text { an } \\
\text { Username, } \\
\text { dan } \\
\text { password } \\
\text { tidak diisi } \\
\text { atau } \\
\text { kosong } \\
\text { kemudian } \\
\text { klik } \\
\text { tombol } \\
\text { Login }\end{array}$ & $\begin{array}{l}\text { Username } \\
\text { : admin } \\
\text { Password: } \\
\text { (kosong) }\end{array}$ & $\begin{array}{l}\text { Sistem akan } \\
\text { menolak dan } \\
\text { menampilka } \\
\text { n pesan } \\
\text { "Password } \\
\text { belum diisi" }\end{array}$ & $\begin{array}{l}\text { Sesuai } \\
\text { harapan }\end{array}$ & Valid \\
\hline 3 & $\begin{array}{l}\text { Mengetikk } \\
\text { an } \\
\text { Password, } \\
\text { dan } \\
\text { username } \\
\text { tidak diisi } \\
\text { atau } \\
\text { kosong } \\
\text { kemudian } \\
\text { klik } \\
\text { tombol } \\
\text { Login }\end{array}$ & $\begin{array}{l}\text { Username } \\
\text { : (kosong) } \\
\text { Password: } \\
\text { admin }\end{array}$ & $\begin{array}{l}\text { Sistem akan } \\
\text { menolak dan } \\
\text { menampilka } \\
\text { n pesan } \\
\text { "Username } \\
\text { belum diisi" }\end{array}$ & $\begin{array}{l}\text { Sesuai } \\
\text { harapan }\end{array}$ & Valid \\
\hline
\end{tabular}

Pada hasil akhir pengujian menggunakan black box tidak ditemukan adanya error atau bug pada setiap proses pengujian fungsional sistem informasi. Dan untuk dapat menjaga kestabilan fungsi dari sistem informasi ini maka diperlukan prosedur penggunaan dan batasan pengguna yang jelas.

\section{KESIMPULAN}

Berdasarkan hasil penelitian yang sudah dilakukan, dapat disimpulkan bahwa sistem informasi UKM STMIK PalComTech dapat membantu para calon anggota UKM dalam hal pendaftaran UKM, selain itu sistem informasi UKM STMIK PalComTech juga dapat membantu anggota UKM STMIK PalComTech, pengurus UKM STMIK PalComTech dan Kemahasiswaan STMIK PalComTech dalam mengecek absensi, kegiatan, data anggota, laporan bulanan dan pengumuman serta materi. 
Adapun saran untuk penelitian ini adalah dilakukan pengembangan sistem informasi ini menjadi sebuah sistem informasi yang dapat dijalankan di platform mobile.

\section{REFERENCES}

[1] F. H. S. Al Haris, S. H. Anwariningsih, and A. J. Barid, "Pemodelan Aplikasi Unit Kegiatan Mahasiswa (Ukm) Universitas Sahid Surakarta," J. Gaung Inform., vol. 8, no. 2, pp. 104-114, 2018.

[2] S. Handayani, A. Anofrizen, and M. Jazman, "SISTEM INFORMASI ECOMMERCE UNTUK JARINGAN PENJUALAN SEPEDA MOTOR BEKAS KABUPATEN KAMPAR (Studi Kasus: Adira Finance)," Jurnal Ilmiah Rekayasa dan Manajemen Sistem Informasi, vol. 2, no. 2, pp. 106-111, 2016.

[3] A. Syahrin, A. Y. Ranius, and W. Wydyanto, "Sistem Informasi Pengelolaan Surat pada Komisi Pemilihan Umum Kota Palemabng Menggunakan Metode Rational Unified Process (RUP)", 2015.

[4] [4] K. S. Ifan Sadewa, "Analisis Dan Perancangan Sistem Indormasi Unit Kegiatan Mahasiswa (UKM) Berbasis Web Pada Universitas Batanghari,” J. Manaj. Sist. Inf., vol. 2, no. 1, pp. 135-146, 2016.
[5] [5] S. Sauri, A. T. Haryono, I. F. Astuti, D. M. Khairina, and D. Cahyadi, "Sistem Informasi Unit Kegiatan Mahasiswa (UKM) Sepakbola Universitas Mulawarman Berbasis Web," Inform. Mulawarman J. Ilm. Ilmu Komput., vol. 10, no. 2, p. 46, 2015.

[6] [6] R. Setiawan and A. Mulyani, "Rancang Bangun Sistem Informasi Unit Kegiatan Mahasiswa Seni Dan Budaya Sekolah Tinggi Teknologi Garut," J. Sekol. Tinggi Teknol. Garut, vol. 14, no. 2, pp. 222-229, 2017.

[7] [7] Rini, Arsia, "Implementasi Metode Rational Unified Process Pada Website PT. Cinta Kasih Pribadina“, TEKNOMATIKA, Vol.07, No.01, Maret 2017.

[8] [8] Elmayati, "Aplikasi Unit Kegiatan Mahasiswa (UKM) pada STMIK MURA LUBUKLINGGAU Berbasis Web," J. Chem. Inf. Model., vol. 53, no. 9, pp. 1689-1699, 2013.

[9] [9] M. S. Mustaqbal, R. F. Firdaus, and H. Rahmadi, "PENGUJIAN APLIKASI MENGGUNAKAN BLACK BOX TESTING BOUNDARY VALUE ANALYSIS (Studi Kasus: Aplikasi Prediksi Kelulusan SNMPTN)," vol. I, no. 3, pp. 31-36, 2015

[10] [10] G. W. Sasmito, "Penerapan Metode Waterfall Pada Desain Sistem Informasi Geografis Industri Kabupaten Tegal,” J. Inform. Pengemb. IT, vol. 2, no. 1, pp. 6-12, 2017. 